Jurnal Informatika dan Rekayasa Perangkat Lunak (JATIKA)
Vol. 1, No. 2, December 2020, 183-191

\title{
APLIKASI PERPUSTAKAAN BERBASIS OPAC (ONLINE PUBLIC ACCESS CATALOG) DI SMK N 1 TALANGPADANG
}

\author{
Willyan Dafit Prayoga ${ }^{1}$, Muhammad Bakri' ${ }^{2}$, Yuri Rahmanto ${ }^{3}$ \\ S1 Informatika, Universitas Teknokrat Indonesia ${ }^{l}$ \\ S1 Teknik Komputer, Universitas Teknokrat Indonesia ${ }^{1,3}$ \\ willy.prayoga25@gmail.com ${ }^{1}$, muhammadbakri@teknokrat.ac.id ${ }^{2}$, yurirahmanto@ teknokrat.ac.id ${ }^{3}$
}

Received: (date month year)Accepted: (date month year) Published: (date month year )

\begin{abstract}
Kejuaruan Middle School (SMK) Negri 1 Talangpadang is a school located in Tanggamus Regency which is located on Jalan Radin Intan No. 35 Banding Agung, Talangpadang District. The library administration applied at SMK N 1 Talangpadang is currently still applying conventional procedures. All administrative activities are still carried out by bookkeeping processes such as processing library materials and services. Library administration must be able to meet all the needs related to library management, administrative activities exist in every library activity both at the secretariat, procurement of library materials, processing, and services (circulation). Library automation is a system that computerizes some of the activities carried out in traditional libraries. By implementing automation, searching library materials can also be faster and more accurate through the OPAC (Online Public Access Catalog). Using the OPAC (Online Public Access Catalog) system is expected to provide solutions to library administration problems that exist at SMK N 1 Talangpadang. The approach used in implementing the OPAC system in library administration uses the UXD user experience (user experience design).
\end{abstract}

Keywords: Libraries, Administration, OPAC, UXD.

\begin{abstract}
Abstrak
Sekolah Menengah Kejuaruan (SMK) Negri 1 Talangpadang adalah sekolah yang berada di Kabupaten Tanggamus yang terleak di Jalan Radin Intan No 35 Banding Agung Kecamatan Talangpadang. Administrasi perpustakaan yang diterapkan pada SMK N 1 Talangpadang saat ini masih menerapkan prosedur konvensional. Semua kegitan administrasi masih dilakukan dengan proses pembukuan seperti pengolahan bahan pustaka dan pelayanan. Administrasi perpustakaan harus dapat memenuhi semua keperluan yang berhubungan dengan pengelolaan perpustakaan, kegiatan administrasi ada dalam setiap kegiatan perpustakaan baik pada sekretariat, pengadaan bahan pustaka, pengolahan, dan layanan (sirkulasi). Otomasi perpustakaan merupakan sistem yang mengkomputerisasikan beberapa kegiatan yang dilakukan pada perpustakaan tradisional. Dengan menerapkan otomasi, penelusuran bahan pustaka juga bisa lebih cepat dan akurat melalui OPAC (Online Public Access Catalog). Dengan menggunakan sitem OPAC (Online Public Access Catalog) diharapkan dapat memberikan solusi terhadap permasalahan administrasi perpustakaan yang ada pada SMK N 1 Talangpadang. Pendekatan yang digunakan dalam penerapan sistem OPAC pada administrasi perpustakaan mengggunakan pengalaman pengguna UXD (user experience design).
\end{abstract}

Kata Kunci: Perpustakaan, Administrasi, OPAC, UXD.

\section{To cite this article:}

Willyan Dafit Prayoga, Muhammad Bakri, Yuri Rahmanto. (2020). Aplikasi Perpustakaan Berbasis OPAC (Online Public Access Catalog) DI SMK N 1 TALANGPADANG. Jurnal Informatika dan Rekayasa Perangkat Lunak, Vol(1) No(2), 183-191.

\section{PENDAHULUAN}

Perpustakaan tidak bisa dipisahkan dari pembelajaran baik di sekolah maupun ditingkat perguruan tinggi dalam mencari ilmu pengetahuan. Perpustakaan adalah institusi pengelola koleksi karya tulis, karya cetak, dan/atau 
karya rekam secara profesional dengan sistem yang baku guna memenuhi kebutuhan pendidikan, penelitian, pelestarian, informasi, dan rekreasi para pemustaka (Indonesia, 2007). Perpustakaan berasal dari kata pustaka, yang berarti buku. Setelah mendapat awalan per dan akhiran an menjadi perpustakaan, yang berarti kitab, kitab primbon, atau kumpulan buku-buku, yang kemudian disebut koleksi bahan pustaka. Jadi perpustakaan bukan hanya gedung atau ruangan yang dipenuhi dengan rak-rak yang berfungsi sebagai tempat penyimpanan buku-buku tanpa ada manfaatnya. Secara prinsip perpustakaan harus dapat dijadikan sebagai sumber informasi yang diperlukan oleh pemakainya. Oleh sebab itu, perpustakaan sebagai penyedia informasi harus mampu meningkatkan dan mengembangkan bahan pustaka (Sutarno, 2008). Perpustakaan merupakan unit kerja dari sebuah lembaga yang berupa tempat menyimpan bahan koleksi pustaka yang diatur secara sistematis untuk digunakan secara berkesinambungan sebagai sumber informasi untuk memperluas ilmu pengetahuan. Oleh sebab itu perpustakaan memiliki beberapa kegiatan diantaranya adalah pengadaan bahan pustaka (pembelian, pertukaran maupun hadiah), pengolahan bahan pustaka (pemberian nomor induk pada buku baru, pembuatan deskripsi bibliografi, penjajaran buku kerak dan sebagainya), pelayanan bahan pustaka yaitu pembuatan kartu anggota, peminjaman buku, pengembalian buku dan sebagainya.

Administrasi perpustakaan merupakan kegiatan pokok yang harus dilakukan oleh sebuah organisasi pepustakaan dalam usaha untuk mempertahankan kelangsungan exsistensi perpustakaan tersebut. Secara umum pengertian administrasi adalah segenap proses penataan kerjasama dari sekelompok orang dengan menggunakan fasilitas dan perlengkapan yang ada untuk memperlancar dan mengefisienkan pencapaian tujuan dari suatu organisasi (Zahara, 2013). Dalam implementasinya, administasi berkembang dan mempunyai tugastugas yang biasa disebut sebagai fungsi administrasi diantaranya adalah fungsi perencanaan, pengorganisasian sampai dengan fungsi pengawasan. Administrasi merupakan suatu kegiatan yang meliputi catat-mencatat, suratmenyurat, pembukuan ringan, ketik mengetik, agenda dan sebagainya yang bersifat teknis ketatausahaan. Administrasi perpustakaan harus dapat memenuhi semua keperluan yang berhubungan dengan pengelolaan perpustakaan, kegiatan administrasi ada dalam setiap kegiatan perpustakaan baik pada sekretariat, pengadaan bahan pustaka, pengolahan, dan layanan/sirkulasi.

Administrasi perpustakaan yang diterapkan pada SMK N 1 Talangpadang saat ini masih menerapkan prosedur konvensional. Semua kegitan administrasi masih dilakukan dengan proses pembukuan seperti pengolahan bahan pustaka dan pelayanan. Pengolahan bahan pustaka meliputi pendataan buku, pemberian nomor, pengatuaran tataletak, penyusunan ke rak-rak, arsip. Pelayanan memiliki beberapa bagian seperti sirkulasi pinjam-meminjam, pendataan anggota, penghitungan denda. Pada setiap bulan petugas organisasi perpustakaan dituntut untuk menyusun pelaporan dari hasil transaksi perpustakaan sebagai bahan evaluasi bulan berikutnya. Dalam proses penyusunan laporan petugas organisasi perpustakaan harus merekap semua data transaksi perpustakaan yang terdapat pada buku besar ke dalam aplikasi pengolahan kata (Microsoft Office). Hal ini dirasa kurang efisien karena akan memakan banyak waktu untuk merekap data adminstrasi perpustakaan yang begitu banyak secara manual dikarenakan belum adanya pangkalan data (database) yang dapat menyimpan data admninistrasi perpustakaan secara menyeluruh, sehingga mengakibatkan sering terjadi keterlambatan dalam pelaporan data administrasi perpustakaan sesuai dengan rentan waktu yang telah ditetapkan. Melihat dari permasalahan yang ada pada perpustakaan SMK N 1 Talangpadang saat ini bahawa perpustakaan belum memiliki pengelolaan administrasi perpustakaan yang terorganisasi dengan baik, sehingga perpustakaan belum bisa memberikan pelayana secara maksimal terhadap calon pembaca maupun peminjam bahan pustaka.

Otomasi perpustakaan merupakan sistem yang mengkomputerisasikan beberapa kegiatan yang dilakukan pada perpustakaan tradisional seperti, kegiatan pengolahan bahan pustaka, sirkulasi, katalog publik OPAC (Online Public Access Catalog), pengadaan (akuisisi), manajemen keanggotaan, pengelolaan terbitan berseri, dan pelaporan. Semua kegiatan tersebut dilakukan dengan menggunakan pangkalan data (database) perpustakaan sebagai pondasinya. Sistem otomasi perpustakaan merupakan suatu manajemen sistem yang dapat mempermudah akses baik bagi pengelola maupun pengguna perpustakaan. Sistem otomasi perpustakaan yang baik adalah sistem yang terintegrasi, mulai dari sistem pengadaan bahan pustaka, pengolahan bahan pustaka, sistem pencarian kembali bahan pustaka, sistem sirkulasi (peminjaman, pengembalian, dan perpanjangan), keanggotaan (membership), pengaturan hak akses keanggotaan, pengaturan denda keterlambatan pengembalian, sistem booking dan sistem reporting aktivitas perpustakaan dengan berbagai parameter pilihan. Lebih sempurna lagi, apabila sistem otomasi dilengkapi dengan barcoding, dan mekanisme pengaksesan data berbasis web dan internet. (Azwar, 2013). Otomasi perpustakaan mutlak diperlukan oleh setiap perpustakaan untuk memaksimalkan tujuan, fungsi, dan tugasnya sebagai lembaga penyedia informasi di era digital. Dengan menerapkan otomasi, penelusuran bahan pustaka juga bisa lebih cepat dan akurat melalui OPAC (Online Public Access Catalog). Pendekatan yang 
digunakan dalam penerapan sistem OPAC pada administrasi perpustakaan mengggunakan pengalaman pengguna (user experience design).

UXD (User Experience Design) adalah tentang bagaimana pengguna merasa, berpikir, dan bereaksi terhadap produk yang kita buat. UX design tidak berbicara mengenai seni, namun lebih ditekankan pada perencanaan interaksi antara pengguna dengan produk. UXD (user experience design) dibagi menjadi lima proses yaitu: bidang strategi (strategic), bidang lingkup (scope), bidang struktur (structure), bidang rangka (skeleton), dan bidang permukaan (surface). Model UXD (user experience design) merupakan model linear dimana satu persatu proses harus dimulai jika proses sebelumnya selesi. Dengan menggunakan sitem OPAC diharapkan dapat memberikan solusi terhadap permasalahan administrasi perpustakaan yang ada pada SMK Negeri 1 Talangpadang. Berdasarkan fitur-fitur yang dimiliki oleh sistem OPAC (Online Public Access Catalog) dapat mendukung dalam proses pengelolan data administrasi perpustakaan seperti mengelola bahan pustaka, mengelola anggota, mengelola sirkulasi pinjam-meminjam, mengelola arsip dan mengelola laporan. Hasil penerapan sisrtem OPAC (Online Public Access Catalog) selanjutnya akan di implementasikan dan diukur kinerjanya. Pengukuran kinerja akan menggunakan user testing sebagai penentu hasil akhir (Najib et al., 2020).

Penelitian ini bertujuan menyesuaikan fiturfitur pada sistem OPAC (Online Public Access Catalog) berdasarkan prosedur yang ada pada administrasi perpustakaan SMK N 1 Talangpadang dengan melakukan pengembangan terhadap sistem tersebut menggunakan pendekatan UXD (User Experience Design) yang berfokus pada pemahaman tentang pengguna, apa yang pengguna butuhkan, apa yang pengguna nilai, kemampuan penggua, dan keterbatasan pengguna. Penerapan sistem OPAC (Online Public Access Catalog) pada administrasi perpustakaan menggunakan pendekatan UXD (User Experience Design) nantinya akan menganalisis kebutuhan awal sebagai strategy sampai pada tahap akhir yaitu surface dengan hasil yang akan disajikan dalam bentuk aplikasi perpustakaan. Penerapan sistem OPAC (Online Public Access Catalog) pada perpustakaan dapat membantu pengelola organisasi perpustakaan dalam mengelola bahan pustaka dan mengelola data administrasi perpustakaan. Aplikasi perpustakaan ini nantinya akan di lengkapi dengan katalog untuk memudahkan calon pembaca dan peminjam (siswa/i) dalam mendapatkan informasi mengenai ketersedian bahan pustaka. Dengan penerapan sistem OPAC (Online Public Access Catalog) pada perpustaan SMK N 1 Talangpadang diharapkan perpustakaan dapat memberikan pelayanan yang baik dan meningkatkan minat calon pembaca dan peminjam (siswa/i) bahan pustaka untuk melakukuan transaksi terhadap perpustakaan.

\section{TELAAH PUSTAKA Perpustakaan}

Perpustakaan Sekolah Menengah Pertama adalah suatu unit kerja yang berada pada Lembaga Pendidikan Sekolah, yang merupakan bagian internal dari sekolah dan merupakan sumber belajar untuk mendukung tercapainya tujuan pendidikan sekolah (wajib belajar 9 tahun). Perpustakaan Sekolah merupakan tempat mengumpulkan bahan perpustakaan, baik tercetak maupun terekam yang dikelola secara teratur dan sistematis untuk memperluas dan memperdalam pengetahuan dengan membaca bahan perpustakaan yang telah diseleksi dan organisir. Secara sistematis dan teratur, sehingga memudahkan mereka dalam mendayagunakannya dalam menunjang optimalisasi pencapaian tujuan pendidikan tujuan pendidikan di sekolah. Melalui Perpustakaan Sekolah khususnya Menengah Pertama sebagai sarana sumber belajar yang berisi aneka ragam bahan perpustakaan, dapat membina minat baca warga sekolah terutama guru dan siswa dan memungkinkan mereka secara berkesinambung memperoleh kesempatan untuk memperluas dan memperdalam pengetahuan dengan membaca bahan perpustakaan yang telah diseleksi dan diorganisir secara sistem dan teratur sehingga memudahkan mereka dalam mendayagunakannya (Sutarno, 2008)

\section{OPAC (Online Public Access Catalog)}

Online Public Access Catalog (OPAC) merupakan sistem katalog terpasang yg bisa diakses secara generik dan bisa digunakan pengguna buat menelusuri data katalog buat memastikan apakah perpustakaan menyimpan karya eksklusif buat menerima berita mengenai lokasinya dan apabila sistem katalog dihubungkan menggunakan sistem sirkulasi, maka pengguna bisa mengetahui apakah bahan pustaka yg sedang dicari tersedia pada perpustakaan atau sedang dipinjam. OPAC adalah perkembangan teknologi pada pada ilmu perpustakaan, selain menaruh kemudahan bagi pengguna pula kemudahan bagi petugas perpustakaan pada melakukan aktivitas pengatalogan.

Tujuan penyediaan OPAC di perpustakaan adalah untuk memberi kepuasan kepada pengguna dan staf perpustakaan dan mempercepat pencarian informasi yang tersedia di perpustakaan (Fitriastuti, 2009). 


\section{METODE PENELITIAN}

\section{Teknik Pengumpulan Data}

Studi literatur adalah langkah pertama dalam penelitian ini. Tujuan utamanya adalah memahami sistem pengolahan data administrasi perpustakaan dan mengidentifikasi masalah (Manullang and Bakri, 2017). Tugas utama yang harus dilakukan dalam tahapan ini meliputi :

1. Kajian Literatur

Kajian literatur bertujuan untuk memperluas wawasan terkait objek yang akan diteliti dengan menelusuri sumber-sumber penelitian yang pernah di lakukan sebelumnya. Sumber tersebut meliputi:

a. Jurnal yang terkait dengan penelitian

b. Buku yang terkait dengan penelitian

c. Skripsi yang terkait dengan penelitian

2. Pengumpulan Data

Pengumpulan data bertujuan untuk memperoleh informasi yang dibutuhkan dalam rangka mencapai tujuan penelitian.

3. Identifikasi

Identifikasi bertujuan untuk mencari, menemukan, mengumpulkan, meneliti, dan mencatat informasi mengenai penelitian terdahulu yang terkait kebutuhan penelitian seperti definisi masalah dan lingkup penelitian.

\section{Identifikasi Target Pengguna}

Identifikasi target pengguna pada penelitian ini meliputi aktor-aktor yang terlibat nantinya dalam penggunaan aplikasi serta peran dan fungsinya (Destiningrum and Adrian, 2017).

1. Aktor Yang Terlibat

Aktor yang terlibat dalam penggunaan aplikasi serta peran dan fungsinya

a. Pustakawan

Pustakawan adalah pengelola administrasi perpustakaan yang bertugas mengelola keseluruhan kegiatan yang ada pada perpustakaan.

b. Siswa

Siswa adalah pengguna biasa yang hanya bisa menggunakan aplikasi OPAC (Online Public Access Catalog) untuk mencari informasi bahan pustaka.

2. User Story

User story merupakan hasil penerjemahan persona khususnya pada bagian need and goals. User story terkait aplikasi adalah sebagai berikut

a. Pustakawan

Pustakawan berperan sebagai pengelola perpustakaan yang memiliki akses penuh untuk mengelola administrasi perpustakaan seperti, pengelolaan bahan pustaka dan pelayanan, pengelolaan arsip dan laporan.

b. Siswa

Siswa berperan sebagai pengguna aplikasi atau pelanggan perpustakaan yang berhak mendapatkan informasi bahan pustaka dan pelayanan yang baik dari pihak pengelola organisasi perpustakaan.

3. Kelayakan Operasi

Proses penggunaan aplikasi ini relatif mudah karena user friendly sehingga pelatihan biasa hanya dalam kurun waktu 1-2 hari

\section{HASIL DAN PEMBAHASAN \\ Analisis dan Perancangan}

Proses penguraian suatu pokok dan menyelidiki kedaan yang sebenarnya dalam sebuah entitas atau guna mencari indikasi komponen dan unsur-unsur penting dalam membangun sebuah sistem informasi. Didalam 
menganalisa rancangan sistem informasi, diperlukan survey proyek sistem guna mengumpulkan data awal kemudian diolah menjadi kesimpulan informasi rencana, menganalisa informasi yang sedang berjalan guna mencari indikasi dan potensi-potensi subsistem yang bisa diciptakan atau revisi, dan mendefinisikan kebutuhan komponen-komponen sistem guna untuk meprioritaskan komponen penting (Setiawansyah, Sulistiani and Darwis, 2020).

\section{Tahap Penentuan Strategi}

Didalam tahap penentuan strategi untuk menentukan langkah yang akan diambil untuk membangun sebuah sistem, dimana untuk membangun sistem tersebut dapat dilakukan dengan tiga tahapan seperti kebutuhan pengguna, tujuan produk, persona.

\section{Tahap Penentuan Struktur}

Tahap penentuan struktur memiliki dua langkah didalamnya mulai dari information arsitecture, interaction design.

\section{a. Information Arsitecture}

Arsitektur informasi merupakan skema organisasi dan navigasi yang memungkinkan pengguna bergerak melalui konten secara efisien dan efektif. Memungkinkan pengguna untuk menemukan informasi dengan mudah.

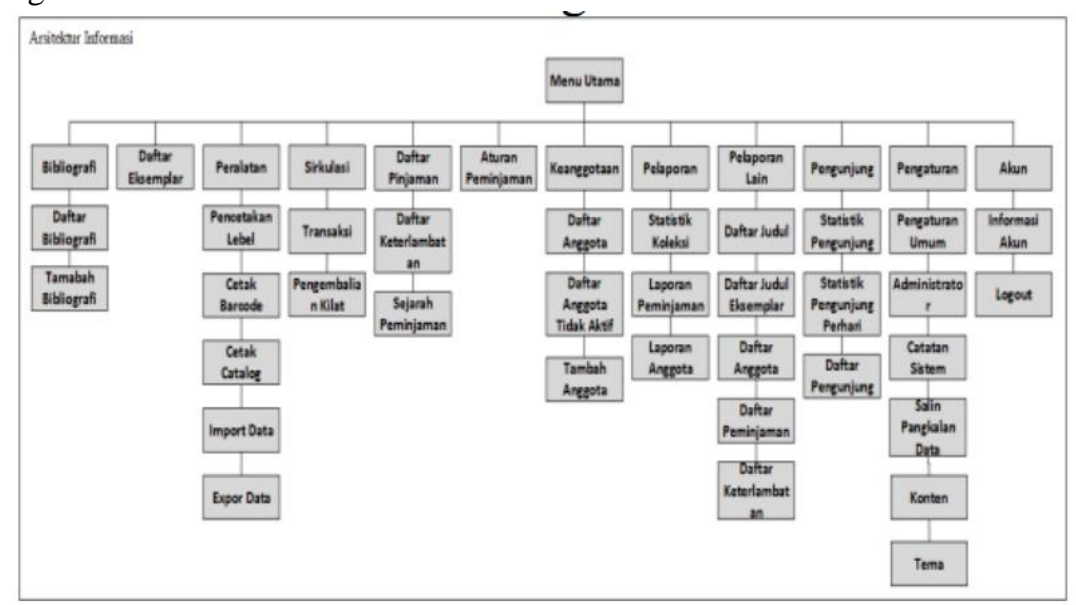

Gambar 1. Arsitektur Informasi

b. Interaction Design

Desain Interaksi adalah menggambarkan kemungkinan perilaku pengguna dan mendefinisikan bagaimana sistem akan mengakomodasi dan menanggapi perilaku. Desain interaksi digambarkan dengan site map. Site map adalah sesuatu yang menggambarkan tentang peta dari website, yaitu segala informasi mengenai halaman atau file-file yang ada pada sebuah website.

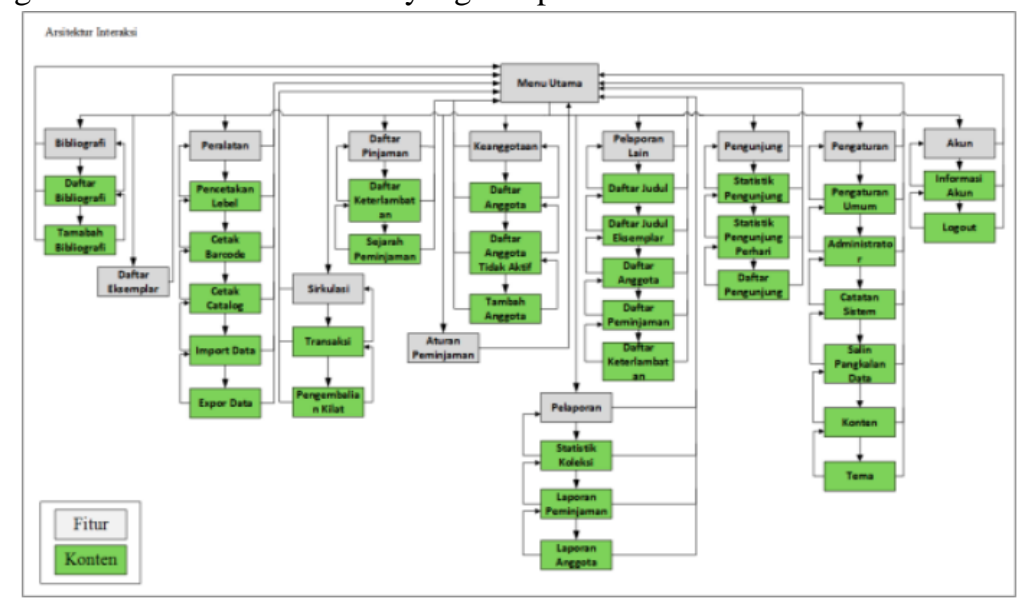

Gambar 2. Desain Interaksi 


\section{Tahap Pengembangan Aplikasi}

Arsitektur aplikasi dengan menggunakan C4 Model yaitu System Conteks Siswa

User atau siswa nantinya dapat mengakses aplikasi OPAC admistrasi perpustakaan tanpa harus daftar ataupun login.

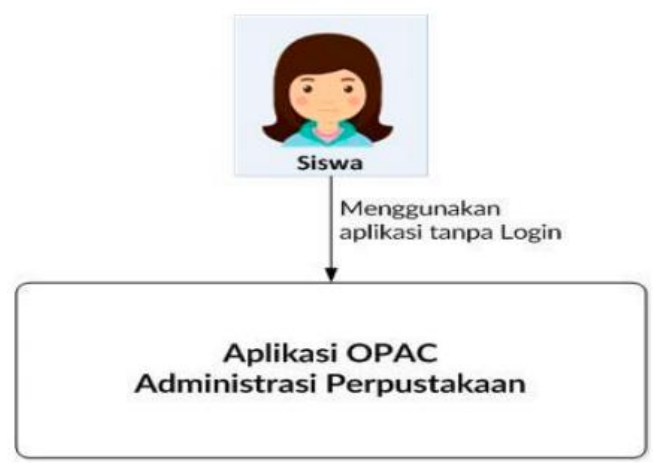

Gambar 3. System Conteks Siswa

\section{System Conteks Pustakawan}

User atau pustakawan nantinya dapat menggunakan dan mengoperasikan aplikasi OPAC administarsi perpustakan melalui login.

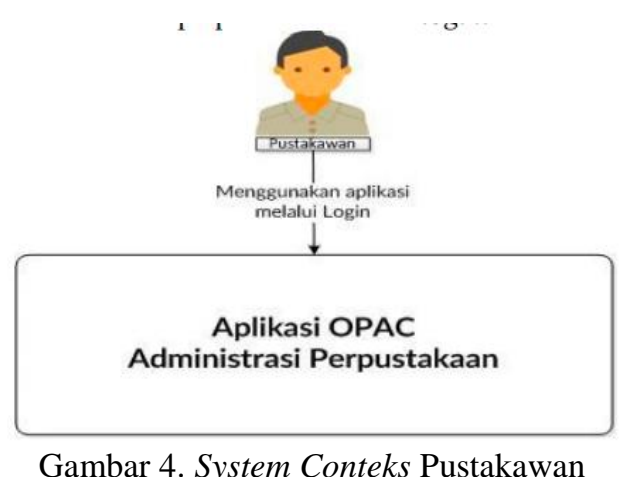

\section{Container Siswa}

User atau siswa dapat mengakses aplikasi OPAC administrasi perpustakaan dengan sistem yang terhubung dan saling berkomunikasi antara satu dengan yang lain, pada saat menampilkan hasil pencarian data akan muncul dalam tab menu dimana data tersebut diambil dari database.

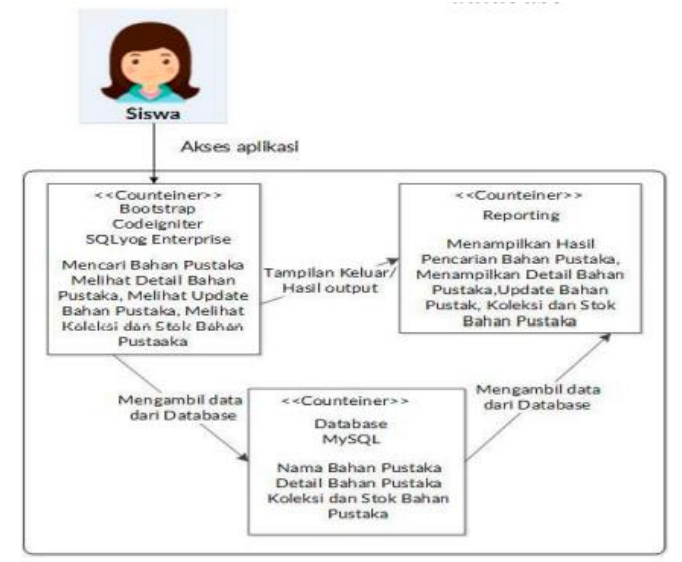

Gambar 5. Container Siswa 


\section{Container Pustakawan}

User atau pustakawan dapat menggunakan dan mengoperasikan aplikasi OPAC administrasi perpustakaan dengan sistem yang terhubung dan saling berkomunikasi antara satu dengan yang lain, pada saat menampilkan hasil pencarian data akan muncul dalam tab menu dimana data tersebut diambil dari database.

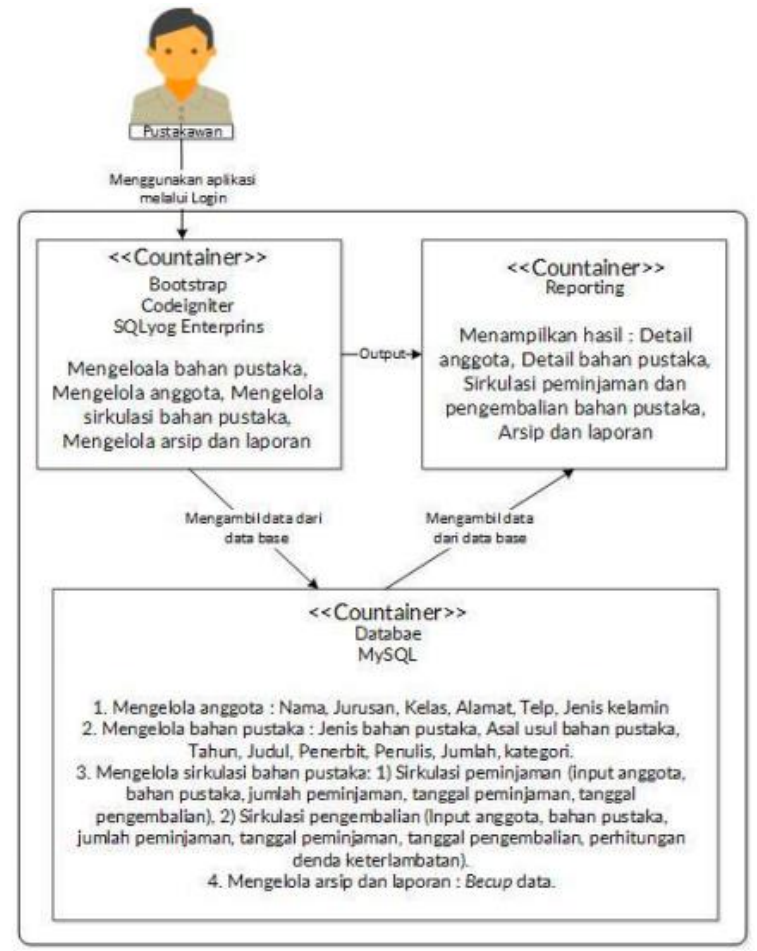

Gambar 6. Container Pustakawan

\section{Implementasi}

Implementasi dilakukan untuk menerapkan perancangan dan pemodelan yang telah diusulkan, dalam tahapannya implementasi memerlukan lingkungan implementasi untuk menjalankan rancangan sistem yang dibuat, dan hasil implementasi untuk mengetahui kesesuaian rancangan yang telah diimplementasikan (Ahdan and Sari, 2020).

\section{Hasil Implementasi}

User interface merupakan tentang cara sebuah sitem berinteraksi atau berkomunikasi dengan manusia. User interface akan mengacu pada beragam aplikasi teknologi mulai dari electronic display, software aplikasi komputer, aplikasi web, aplikasi mobile, hingga aplikasi kiosk Informasi public. Kioks adalah peralatan sistem informasi publik yang dirancang sedemikian rupa yang ditujukan untuk beragam kondisi user, baik secara usia, gender, latar belakang kultural, tingkat pemahaman dan pendidikan bahkan kondisi keterbatasan fisik yang berbeda.

\section{Instrumen Pengujian}

Instrumen dalam pengujian ini menggunakan standart ISO 25010. Hal tersebut membantu dalam melakukan analisis kualitas dari perangkat lunak yang dikembangkan, dalam pengujian dilakukan pada penyesuaian kebutuhan pengguna dan penelitian sehingga pengujian hanya dilakukan pada karakteristik usability (Megawaty et al., 2020).

\section{User Task Flow}

Berikut merupakan user task flow untuk aplikasi administrasi perpustakaan SMK N 1 Talang Padang

a. User Menambahkan Buku Baru

b. User Merubah Eksemplar

c. User Memasukan Data Transaksi 
d. User Menambahkan Aturan Peminjaman

e. User Menambahkan Anggota Baru

f. User Menggunakan Peralatan

g. User Menambahkan Data master file

h. User Menambahkan Data Refrensi

\section{Pengujian Understandibility}

Pengujian yang dilakukan dengan cara menganalisa kemampuan pengguna dalam menggunakan/mengoprasikan aplikasi tanpa adanya pelatihan maupun pendampingan penggunaan, hal tersebut sesuai dengan penerapan pengujian standrt ISO 25010 karakteristik usability tast. Dalam tahap pengujian understandibility peneliti memberikan 24 task kepada pengguna untuk diselesaikan. Dari hasil analisa yang dilakukan, pengguna dapat memahami penggunaan aplikasi, dan menyelesaikan tugas yang di berikan dengan rentan kesasalahan yang rendah.

3. Pengujian Memorability

Hasil pengujian yang dilakukan secara berkala, pengguna dapat mengingat kembali dalam menggunakan aplikasi dimana tingkat kesalahan berkurang yaitu pada pengujian pertama pengguna melakukan 3 kesalahan dari 24 tugas yang diberikan dan pada pengujian berikutnya pengguna dapat mengurangi kesalahan dimana dari 24 tugas yang diberikan pengguna hanya melakukan 2 kesalahan.

4. Error of Use

Hasil pengujian memorability, pengguna melakukan 2 kesalahan dari total 24 task yang diberikan, berikut hasil dari error of use yang dinyatakan dalam bentuk persentase

$$
\begin{gathered}
\text { Keberhasilan : } 24 \text { Task }=\left(\frac{22}{24}\right) \times 100 \%=92 \% \\
\text { Kesalahan : } 24 \text { Task }=\left(\frac{2}{24}\right) \times 100 \%=8 \%
\end{gathered}
$$

Dari hasil analisa pengujian memorability tingkat keberhasilan pengguna $92 \%$ dan pengguna mengalami kesalahan sebanyak $8 \%$. pengguna mengalami kesalahan berulang dalam melakukan pemilihan bentuk file yang akan diunggah.

\section{Satisfaction}

Keberhasilan diukur berdasarkan analisa kemampuan pengguna dalam pengenalan, penggunaan serta penyelesaian task yang diberikan pada saat melakukan pengujian aplikasi. Hasil keberhasilan pengguna dalam menggunakan aplikasi dapat dilihat pada grafik berikut ini.

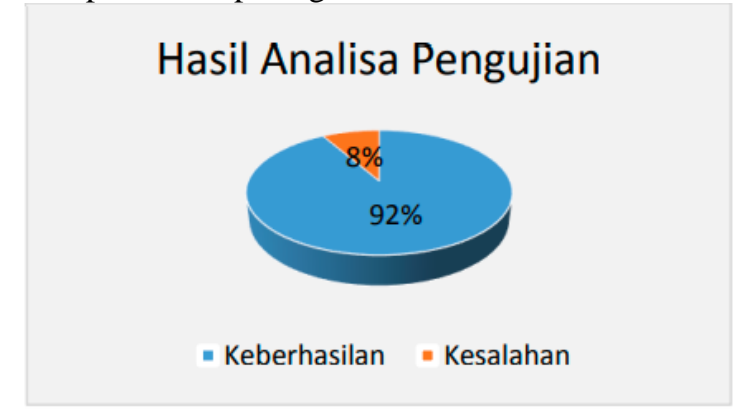

Gambar 7. Grafik Analisa Pengujian

Berdasarkan grafik analisa pengujian diatas menegaskan bahwa tingkat keberhasilan pengguna dalam menggunakan aplikasi jauh lebih tinggi dibandingkan dengan tingkat kesalahan yang dilakukan yaitu $92 \%$ keberhasilan dan $8 \%$ kesalahan.

\section{SIMPULAN}

Penelitian ini dapat disimpulkan beberapa hal yaitu Pengujian dilakukan dengan menggunakan Usability Testing, hasil dari pengujian menunjukkan pengguna dapat berinteraksi dengan baik terhadap aplikasi dengan 92 $\%$ keberhasilan, dan $8 \%$ kesalahan. Mengimplementasikan aplikasi administrasi perpustakaan dapat membantu 
siswa dalam mencari informasi bahan pustaka dan dapat membantu pustakawan dalam mengelolala administarasi perpustakaan.

\section{UCAPAN TERIMA KASIH}

Puji syukur penulis panjatkan kepada Allah SWT, karena atas berkat dan rahmat-Nya, penulis dapat menyelesaikan penelitian ini. Penulisan Penulis menyadari bahwa, tanpa bantuan dan bimbingan dari berbagai pihak, dari masa perkuliahan sampai pada penyusunan penelitian ini. Oleh karena itu, penulis mengucapkan terima kasih kepada:

1. Bapak Dr.H.M. Nasrullah Yusuf S.E, M.B.A., selaku Rektor Universitas Teknokrat Indonesia;

2. Bapak Dr. H. Mahathir Muhammad, S.E., M.M., selaku Dekan Fakultas Teknik dan Ilmu Komputer, Universitas Teknokrat Indonesia;

3. Ibu Dyah Ayu Megawaty, M. Kom. selaku Ketua Program S1 Informatika, Fakultas Teknik dan Ilmu Komputer, Universitas Teknokrat Indonesia;

Akhir kata, penulis berharap semoga Allah SWT berkenan membalas segala kebaikan semua pihak yang telah membantu dan semoga penelitian ini membawa manfaat bagi pengembangan ilmu.

\section{REFERENSI/DAFTAR PUSTAKA}

Ahdan, S. and Sari, P. I. (2020) 'PENGEMBANGAN APLIKASI WEB UNTUK SIMULASI SIMPAN PINJAM (STUDI KASUS: LEMBAGA KEUANGAN SYARIAH BMT L-RISMA', Jurnal Tekno Kompak, 14(1), pp. 33-40.

Azwar, M. (2013) 'Membangun Sistem Otomasi Perpustakaan dengan Senayan Library Management System (SLiMS)', Khizanah al-Hikmah: Jurnal Ilmu Perpustakaan, Informasi, dan Kearsipan, 1(1), pp. 19-33.

Destiningrum, M. and Adrian, Q. J. (2017) 'Sistem Informasi Penjadwalan Dokter Berbassis Web Dengan Menggunakan Framework Codeigniter (Studi Kasus: Rumah Sakit Yukum Medical Centre)', Jurnal Teknoinfo, 11(2), p. 30. doi: 10.33365/jti.v11i2.24.

Fitriastuti, F. (2009) 'Aplikasi OPAC (Online Public Access Catalog) pada Sistem Informasi Perpustakaan Berbasis Mobile', KATA PENGANTAR, p. 13.

Indonesia, P. N. R. (2007) 'Undang-Undang Republik Indonesia Nomor 43 Tahun 2007 Tentang Perpustakaan’. Pemerintah Negara Republik Indonesia.

Manullang, I. T. S. and Bakri (2017) 'PENGEMBANGAN APLIKASI MOBILEUNTUK PELELANGAN KOPI MENGGUNAKAN PLATFORM ANDROID'. Perpustakaan Teknokrat.

Megawaty, D. A. et al. (2020) 'SISTEM MONITORING KEGIATAN AKADEMIK SISWA', 14(2), pp. 98-101.

Najib, M. et al. (2020) 'MIT APP INVERTOR PADA APLIKASI SCORE BOARD UNTUK PERTANDINGAN OLAHRAGA BERBASIS ANDROID', Tekno Kompak, 14(2), pp. 115-120.

Setiawansyah, Sulistiani, H. and Darwis, D. (2020) 'Penerapan Metode Agile untuk Pengembangan Online Analytical Processing ( OLAP ) pada Data Penjualan ( Studi Kasus : CV Adilia Lestari )', Jurnal CoreIT, 6(1), pp. 50-56.

Sutarno, N. S. (2008) Kamus perpustakaan dan informasi. Jala Permata.

Zahara, Z. (2013) ‘Organisasi dan Administrasi Perpustakaan Sekolah'. 